\title{
The House is on Fire: Housing and the 2015 General Election
}

Un sujet brûlant? Le logement et les élections de 2015

David Fée

\section{(2) OpenEdition}

\section{Journals}

Electronic version

URL: http://journals.openedition.org/rfcb/592

DOI: $10.4000 / \mathrm{rfcb} .592$

ISSN: 2429-4373

Publisher

CRECIB - Centre de recherche et d'études en civilisation britannique

\section{Electronic reference}

David Fée, «The House is on Fire: Housing and the 2015 General Election », Revue Française de Civilisation Britannique [Online], XX-3 | 2015, Online since 01 December 2015, connection on 01 May 2019. URL : http://journals.openedition.org/rfcb/592 ; DOI : 10.4000/rfcb.592

This text was automatically generated on 1 May 2019.

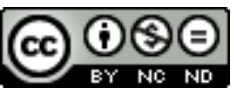

Revue française de civilisation britannique est mis à disposition selon les termes de la licence Creative Commons Attribution - Pas d'Utilisation Commerciale - Pas de Modification 4.0 International. 


\title{
The House is on Fire: Housing and the 2015 General Election
}

\author{
Un sujet brûlant? Le logement et les élections de 2015
}

\section{David Fée}

1 Housing was a key electoral issue during the post-war years because of an enduring shortage. It remained so throughout the Thatcher years because of the Conservative governments' emphasis on home-ownership as well as the proven connection between home-ownership and voting behaviour. ${ }^{1}$ It then experienced a decline in visibility in the 1990s and 2000s due to politicians' conviction that the housing shortage was over and the emergence of a housing consensus ${ }^{2}$ between the two main parties that deprived homeownership of its electoral importance.

2 However, the 2015 general election saw housing move up the political agenda and burst onto the political stage. Hardly a week went by without press articles, TV programmes or public opinion polls highlighting the housing situation in the UK. This rise culminated in a TV debate between party leaders in April 2015 when all contestants were asked about their housing policies. It appeared then that the housing crisis that had been building up since the early 1980 s had finally been given official recognition and housing had regained its former salience.

3 But housing issues are not restricted to supply or home-ownership; they also encompass welfare policies. The 2015 general election brought to an end five years of coalition government that were marked by the introduction of major reforms to welfare and as a result to housing. These reforms contributed to pushing the British housing system further away from the classic social democratic welfare state model, as defined by G. Esping Andersen, ${ }^{3}$ towards greater commodification and financialisation. As a result, they led to renewed militancy in UK society in the months leading up to the general election in order to denounce the housing choices made between 2010 and 2015 and their consequences.

4 This article will review the reasons why housing became a more salient electoral issue during the run-up to the 2015 general election and examine whether voters' greater 
awareness of the housing crisis and readiness to mobilize translated into votes, in a country where a large majority of the population own their homes.

In order to throw light on these questions, in the first section I shall look at the growing activism that has characterized UK society since 2010 in the field of housing. In the second section, I shall examine the causes of the militancy and the reasons why a growing number of citizens are turning to direct action. I shall then move on to the main parties' reaction and finally explore the electoral dimension of housing.

\section{The electoral campaign and the rise of a housing movement}

6 The five years that followed the formation of the coalition government in May 2010 were marked by the rise of a housing movement that sought to bypass traditional representative democracy in order to bring housing issues in the UK to politicians' and the public's attention. As the day of the general election drew nearer, it gathered momentum. Although protest flared up occasionally in the 1990s and 2000s, ${ }^{4}$ the last five years were unusual in the growing number of protests, occupations and debates as well as the nature of the movements and organisations joining forces prior to the general election. $^{5}$

7 The rise of the housing movement cannot be dissociated from the formation of a coalition government and the policy choices made as early as 2010. The call to arms came from the Chancellor's emergency budget, announced six weeks after the election, in June 2010. On the basis of what was said to be a rise in welfare spending under Labour from $£ 132$ billion to $£ 192$ billion between 2000 and 2010 (including an increase from $£ 14$ billion to $£ 21$ billion in housing benefit) George Osborne announced his decision to cut the welfare budget by $£ 11$ billion by 2015 . These figures were compounded by further cuts that were made public in October of that year in the Comprehensive Spending Review. Beside a reduction of social housing funding from $£ 8.4$ billion in 2008-2011 to $£ 4.4$ billion in 2011-2015, ${ }^{6}$ G. Osborne also revealed government plans to reform the social housing sector: housing associations were to be given the right to charge new tenants up to $80 \%$ of the market rents so as to build 150,000 new affordable homes over the next four years, housing benefit (HB) for a flat would no longer be paid to young people below the age of 35 (but only the Shared Accommodation Rate), and the housing allowance paid to private sector tenants would be capped at $£ 417$ a week for a four-bedroom house. It was no longer to be calculated on the basis of the median rent by a housing officer but on the bottom 30 th percentile of local market rents. ${ }^{7}$ These measures as well as more controversial ones (see next section) were included in the Welfare Reform Act that received royal assent on 8 March 2012.

8 The first sign of things to come was the decision by the Occupy London movement that started in October 2011 to set up a housing think tank in order to make proposals to the government on housing supply, house prices and homelessness. ${ }^{8} \mathrm{~A}$ year later, in October 2012, the first protest against the demolition of a council estate in London took place at the Carpenters Estate in Newham. The coming into effect of the Welfare Reform Act in April 2013 led to the first demonstrations in March 2013 against some of the provisions made in the Act regarding the calculation of the Housing Benefit (Bedroom Tax, see next section) and to the setting up of the Radical Housing Network to bring together various 
housing campaign groups. The salience of housing was increased in the run-up to the general election by the decision of some British celebrities to wade into the debate. In October 2014, Comedian Russell Brand came out in favour of a group of mothers threatened with repossession and rehousing outside of London (Focus E15 mums) by Newham council, thus highlighting the extent of homelessness in London. One month later, Russell Brand went on to give his support to another cause that publicized the issue of uncontrolled rents in the capital. The high profile protest staged outside Downing Street to denounce the sale of a 1930 charitable trust estate (New Era in Hackney) to an American investment company attracted so much media attention that it forced the Mayor of London to step in and the Greater London Authority to broker an alternative solution in order to protect the tenants from uncontrolled rent increases. ${ }^{9}$

The final five months to polling day saw increasing mobilization in order to put the housing issue centre stage in the election campaign and to step up pressure on politicians. Tactics ranging from direct action through celebrity personalised campaigns to the use of social media were employed. On $31^{\text {st }}$ January 2015, the March for Homes gathered some 6,000 housing activists, union representatives and campaigners who marched on City Hall to denounce the housing situation in London and demand rent controls, as well as an end to the demolition of council homes and the bedroom tax. The march was followed by the occupation of the boarded up Aylesbury Estate and the decision by another famous comedian, Eddie Izzard, in February to add his voice to those of the Sutton estate tenants threatened with eviction because of the imminent redevelopment. In the following months, similar protests and occupations took place in Brixton (Loughborough Estate), in Barnett (Sweets Way) and other parts of London. The extent of the civil mobilization led to the organization of the 'Homes for Britain Rally' in Westminster on 17 March. The event gathered 2,500 housing professionals and members of the public calling "for an end to the housing crisis within a generation". It saw politicians of all hues (Nigel Farage, Caroline Lucas, Grant Shapps, Hilary Benn, etc.) address the assembly and promise to build more homes, less than two months before polling day. ${ }^{10}$

The unprecedented growth of a housing campaign movement since the 1960s leaves us with several questions: first, why did housing feature so much in the run-up to the 2015 general election? Indeed, the previous poll had only seen a timid attempt by the Chartered Institute for Housing (backed by the House Proud campaign) to raise unsuccessfully - the profile of housing. Second, how did politicians react to the changing context? Third, did the movement have an impact on the outcome of the election and the public?

\section{A worsening housing crisis}

11 One first element of answer lies in the low housebuilding level that characterised the years between the two general elections and its consequences on the lives of many Britons. In 2010, the Conservative Party had gone into battle promising to abolish the delivery targets imposed by the Labour government on councils through new regional planning structures after 1997. Quite logically, its 2010 manifesto did not contain any ${ }^{11}$ and nor did the Coalition's government document. ${ }^{12}$ However, on the basis of the target raised by Gordon Brown in 2007 to 240,000 new homes a year ${ }^{13}$ and the conclusions of the 2003 Barker report into housing supply ${ }^{14}$, most specialists regard the Coalition's 
achievements as wholly inadequate. The banking crisis and its spin-off effects caused housebuilding to fall from a peak of 219,000 new homes in 2006-2007 in the UK to an alltime low of 135,000 in 2012-2013. Since then, housebuilding has slightly recovered but remained far too low, at 141,000 in $2013-2014^{15}$. The causes of this debacle are controversial and numerous: the planning system is said to be too slow by the Conservative party as well as by the House Builders Federation despite numerous reforms under the previous Labour government. The HBF argue that 150,000 plots are waiting for planning permission and that there is an overall lack of available land. ${ }^{16}$ Conversely, countryside protection organisations contend that developers indulge in land banking in order to maximize their profits and do not respond to market signals. The construction industry is often blamed for its poor efficiency, too, and its high degree of concentration. ${ }^{17}$ Finally, the decline of social house building cannot be stressed enough, down from close to 200,000 units in $1969-70$ to some 30,000 in 2013-14. This is clearly due to a drastic reduction in public spending since the late 1980s, although local authority housebuilding has been growing since $2008^{18}$. This needs to be contrasted with the 78,000 social homes thought to be needed in England alone every year. ${ }^{19}$ Out of the $£ 19.5$ billion spent on building 217,000 affordable homes between 2011 and 2015, only $£ 1.8$ billion came from the coalition government, the rest from housing associations and the previous Labour government ( $£ 15$ billion and $£ 2.3$ billion respectively). ${ }^{20}$ Funding social housing was certainly not a priority of the coalition government.

The consequences of a very dysfunctional UK housing system were plain to see by May 2015. Since 2010, house prices have risen so fast that the percentage of home owners in England has carried on declining from $71 \%$ in 2003 to $63 \%$ in 2013. Young people aged 25-34 are particularly affected, with a decline in owner occupation from $59 \%$ in 2003 to $36 \%$ in 2013. As a result of this rise in house prices, the percentage of English households renting in the private sector increased from $11 \%$ in 2003 to $19 \%$ in 2013-14. ${ }^{21}$ Rents have been rising steadily (by $32 \%$ between 2008 and 2014 in the social sector and $15 \%$ in the private rented sector) and this has led to a growing proportion of tenants being unable to meet the cost of renting without receiving housing benefit (hence the ballooning Housing Benefit total). The percentage of working households in receipt of $\mathrm{HB}$ has indeed increased from $19 \%$ in 2003 to 2008 to $32 \%$ in 2013 in the social sector and from $7 \%$ to $14 \%$ in the private sector. ${ }^{22}$ Other signs of the worsening situation can be seen in the growing proportion of households classified as overcrowded in the private rented sector ${ }^{23}$ as well as households found to be homeless since 2008 (81,000 in 2013-14) ${ }^{24}$ or the 1.4 million people on council waiting lists in England alone..$^{25}$

\section{Controversial Policy Choices}

As seen in the first section, the Coalition's early policy and financial choices triggered the rise of the housing movement. Indeed, these choices were said to be unfair and leading to social polarisation. Their consequences were denounced not just by housing activists but by housing professionals too. They were relayed and given extensive coverage by the media and as such helped to give housing greater electoral visibility ${ }^{26}$.

14 The attempts by London councils at finding cheaper solutions to house priority homeless households were indeed widely publicised. Their task has been made all the more difficult in a national context of acute social housing shortage as the welfare reforms that came into effect as of April 2013 (see first section) drastically reduced their scope for action. As 
a result of the decision by the coalition government to cap overall entitlement to welfare to $£ 500$ a week for a couple or single-parent households and $£ 350$ for single person households, councils have been forced to cut the housing benefit of those households who received welfare payment in excess of the cap. The consequences were said to be the eviction of private rented sector tenants unable to pay their rents, growing homelessness as well as tensions in the government's housing policy. ${ }^{27}$ This has made it almost impossible for councils to house priority households in the private sector in expensive areas - for lack of social homes - at rents below the overall cap or below the rent cap set in 2012 by the Welfare Reform Act (see previous section). As a result, some councils in the South East (Westminster, Oxford, Newham etc.) have been striking deals with local housing associations as far as Birmingham or Stoke on Trent to relocate their homeless households at a cheaper rent. Some are even offering to pay those housing associations more than the local housing allowance if they agree to take their tenants on. ${ }^{28}$ Since 2011, it is estimated that 50,000 families have been moved out of London ${ }^{29}$ and private landlords have been shown to be increasingly reluctant to rent to Housing Benefit claimants..$^{30}$

However, although benefit capping fundamentally alters welfare in England, it was not the object of media attention and did not draw the ire of housing activists and professionals as much as another cause that emerged at some point in 2014, namely the bedroom tax.

The spare room subsidy removal (its proper denomination in official documents) is a provision of the 2012 Welfare Reform Act. The Act introduced a major change to Housing Benefit in as much as the (capped) benefit is henceforth calculated on the basis of the size of the accommodation occupied by a household in the social housing sector: one room is allowed for a couple or each person of a household with the exception of children under 16 of the same gender or children under 10 of the opposite gender (expected to share a room) and disabled tenants or their partner who needs an over-night resident carer. Those working age tenants whose accommodation is thought to be too large will lose a part of their benefit, the total of which will be reduced by $14 \%$ for one spare bedroom and $25 \%$ for two or more spare bedrooms. ${ }^{31}$ The official explanation was that the change would bring the rules in line with those in the private rented sector, and more generally improve incentive to work. ${ }^{32}$ But the unofficial one was that it would help free social homes for families and match needs and supply without building more. Even before the reform came into effect on $1^{\text {st }}$ April 2013, protests were organised across the country by political organisations such as Labour Left or civil ones like Defend Council Housing or the Anti-bedroom Tax and Benefit Justice Federation. The movement culminated in a National Meeting on $7^{\text {th }}$ June 2014 in Manchester and the drafting of a Charter for Benefit Justice.

17 Housing institutions like Shelter estimated that a third of all working age benefit claimants living in the social sector would be affected and would have to move or lose money. Shelter therefore came out against the bedroom tax. It opposed the change on a number of grounds including the increased risk of falling into arears and eviction for lowincome households, the need for households to cut down on essential spending to compensate for lost money or the impossibility to downsize due to a shortage of homes. Shelter waded into the debate, especially criticising the government for not taking into account the needs of disabled households and leaving to local authority discretion the possibility to allocate an extra room to disabled households in very limited 
circumstances. The straightjacket of the law, they said, also failed to take into account the specific needs of divorced households while creating a bureaucratic nightmare, a system far more intrusive than in the private rented sector. ${ }^{33} \mathrm{~A}$ Court of Appeal Case in 2012 on behalf of disabled children and the extent of the mobilisation before $1^{\text {st }}$ April 2013 led to a few government concessions for foster parents and parents with children in the armed forces.

\section{More Radical Proposals}

18 A final reason why housing was given wider media coverage and moved centre stage has to do with some of the proposals included by the two main political parties in their manifestos in the run-up to the election. Two proposals in particular attracted much attention and caused a media storm as they were seen as an expression of the radicalisation of Labour and the Conservatives as well as a return to the days when housing was a fighting ground for the two parties.

Closer to the date of the general election, the Labour Party September 2014 conference triggered a new controversy. On that occasion, Ed Miliband got the principle of a new housing tax adopted by Conference and made it an election pledge. Originally a Lib-Dem idea, the Mansion Tax (as it was immediately dubbed) was to have been a new tax on the owners of the 108,000 homes valued at more than $£ 2$ million in the UK ( $88 \%$ of them in London and $35 \%$ of the total tax in Kensington and Chelsea) ${ }^{34}$ Although Labour did not specify the precise rate of taxation and simply referred to four bands, it argued that it would raise $£ 1.2$ billion that could be used to fund the NHS. The announcement immediately came under fire from the Conservative party and created dissensions in Labour itself and criticisms from Labour donors. The right-wing press, rarely a friend of Labour, came out fighting with headlines like "Middle Class Families hit by Labour's Mansion Tax" ${ }^{\prime 35}$ and articles arguing that millions of ordinary home owners would suffer because of the increased volatility in the housing market it would create. ${ }^{36}$ Minor celebrities like Myleene Klass stepped in and grilled Ed Miliband on ITV in January 2014, arguing that the tax would hit cash poor but property rich Britons, giving the polemic a higher profile. Ed Balls, as a result, was forced to appear on further TV programmes (such as Sky News on 23 April 2015) to explain the tax to viewers and try to counter criticisms. The polemic was amplified and given a more respectable and serious dimension when Kate Barker, the economist commissioned by the previous government to advise on housing supply (see section 2), criticised the plan saying it would be "very disruptive for the market". ${ }^{37}$

The announcement by the Tories on 14 April (less than a month before polling day) that they intended to give housing associations tenants the right to buy their home in their manifesto opened a last front between the two main political parties and brought housing into the spotlight of the campaign again. The Tory manifesto indeed pledged to extend the Right to Buy introduced by Margaret Thatcher in 1980 to housing association tenants (some 1.3 million tenants) on the basis that the RTB was unfairly restricted to local authority tenants and the Conservatives wanted to help "working people" and give them " the security to build a brighter future" ${ }^{38}$ In order to pre-empt any criticism about the reduction of social stock the sales would cause, it added that local authorities would be required to sell off their most expensive properties on the market when they became vacant in order to pay for the building of replacement properties. ${ }^{39}$ This announcement 
came three years after the decision by the Coalition to revive the Right to Buy (RTB) by removing the restrictions imposed by the previous Labour government. Between 1997 and 2010, the discounts available to buyers in areas under housing stress were indeed lowered and the qualifications altered. Instead, the Coalition chose to raise discounts in London to $£ 75,000$ in April 1012, leading to a growing number of council homes being sold (from 3,800 units in 2008-09 to 15,600 in 2013-14), although this remained far below the 2003-04 Labour peak of 84,000, not to mention the 1982 Conservative peak of $167,000 .{ }^{40} \mathrm{In}$ 2015 , the Conservative pledge to offer discounts close to £78,000 in England and £104,000 in London to housing association tenants smacked of a desire to undercut its opponents and was revealed to be a U-turn on the subject in the run-up to the election. ${ }^{41}$

21 Although not entirely novel and limited in practice, contrary to Tory rhetoric, ${ }^{42}$ the extension of the Right to Buy to housing associations in England, ${ }^{43}$ at a time of acute social housing shortage and growing waiting lists, did not fail to spark off a public debate and brought the risk of a legal challenge against the government one step closer. ${ }^{44}$ The National Housing Federation (the umbrella organisation for housing associations) immediately came out against the proposals and unveiled a YouGov poll that appeared to support its position. ${ }^{45}$ It argued that housing associations would be forced to concentrate on replacing homes and not building additional ones, that it set a dangerous precedent of the government interfering in the independent sector, the total discounts (some $£ 12$ billion) could fund one million shared ownership homes and that it would not improve the housing situation of private sector tenants. ${ }^{46}$ Financial experts, for their part, warned about the risks of the policy to the credit worthiness and balance sheets of housing associations and ultimately risks of insolvency for some of them due to the reduced value of their assets and consequently borrowing problems. ${ }^{47}$ Even the Institute of Fiscal Studies, not exactly a left-wing body, waded in and pointed to the many questions raised by the Tory plan: uncertainties surrounding the revenues that housing associations could generate by selling their most expensive homes or the cost of RTB discounts for housing associations and that of having to replace sold properties. It pointed out that the $£ 4.5$ billion in earnings from the sales expected by the government were at odds with its own calculation ${ }^{48}$ and added that the policy was likely to lead to further housing segregation by concentrating new homes in low cost areas and selling the most valuable ones in expensive areas.

\section{Addressing the crisis? The party manifestos}

In the face of such media coverage and activism, how did political parties react? Despite the crisis, it appears that the manifestos of the main political parties mostly reflect the consensus that has prevailed in housing over the last 40 years ${ }^{49}$, with some variations. In many ways, they failed to address the affordability and supply crisis properly, hence the criticisms they drew from housing organisations. ${ }^{50}$ Indeed, in a country where home owners remain a majority of the population, where most tenants aspire to becoming home owners ${ }^{51}$ and home-ownership meshes so closely with the rest of the economy (through mortgaging, remortgaging, equity withdrawal), it is tempting for parties to focus on the issue at the expense of equally important other housing matters. This accounts for the fairly traditional pledges included in the main political parties' manifestos. 

promised to extend home-ownership (to another 1 million people in 5 years). Being in power, they celebrated what they described as "housebuilding at its highest" ${ }^{52}$, failing however to explain that housebuilding was simply recovering from its post-2008 collapse. In a context of spiralling house prices that makes it very difficult for young people to become owners, the Conservatives focused on first-time buyers. The housing crisis, if there is such a thing to the Tories, was clearly construed as a problem of access to the housing ladder. Describing themselves as "the party of home-ownership" (an echo of Anthony Eden's slogan of "property-owning democracy"), they reminded voters of the introduction of the Help to Buy scheme, promised to extend it to 2020 and provide new government help (IPSA). Furthermore, the manifesto also marked a return to Thatcherite tenets in the shape of a revived and polemical Right to Buy (see previous section). Apart from a brief reference to "homes to rent", affordable housing itself (a term decried by housing specialists for being too vague and often close to market levels) was only defined in connection with home-ownership: 200,000 affordable homes were to be sold to the under-40s, at $20 \%$ below the market price (as revealed in a speech by D. Cameron in Colchester on 2 March). As part of their efforts to cut public spending and prevent voters from drifting to UKIP, the manifesto pledged to withdraw Housing Benefit from certain categories of the population (18-21 year-olds on job seekers allowance, EU workers) or ban them from accessing social housing (EU workers). Finally, in keeping with their 2010 promise to create a 'Big Society' and the 2011 Localism Act, it also expressed support for locally-led Garden Cities.

Although explicitly referring to a "housing crisis", the Labour manifesto's housing section remained strikingly short and vague. In it, the party pledged to help (young) people into home-ownership and to build Garden cities, too. However, unlike its opponents, it also looked beyond home owners, ${ }^{53}$ promising to get 200,000 homes built a year (to buy and rent) and took into account various aspects of the crisis: the private rented sector (infamous for its excesses) was to be controlled by introducing three-year secure tenancies, a register of private landlords and a limit to excessive rent rises. A more traditional, social agenda was also visible in the denunciation of the increase in homelessness and rough sleeping, a pledge to abolish the Bedroom Tax (see previous sections) and an indication that it would allow public housebuilding again.

There were echoes of Labour's manifesto in the Liberal Democrats' in so far as it also committed the party to a higher housebuilding target $(300,000)$, ten Garden Cities, helping local authorities build again and protecting private renters. ${ }^{54}$ However, the manifesto was far more detailed and clearly distanced itself from the policies introduced during their years in the Coalition, policies that had fuelled housing activism as seen before: the shared accommodation rate was to be reviewed and the spare room subsidy reformed. It was also more interventionist, vowing to tackle 'buy to leave empty' investment, tax second homes and restore local authority control of RTB. Oddly enough, many proposals designed to boost supply were redolent of the New Labour years (reforming the planning system, assessing better local housing needs through price signals, prioritising brown field development and planning housing needs over 15 years) when these were not found in Labour's manifesto. In a word, the Liberal Democrats put more onus on housing than the other two main parties although, paradoxically, their manifesto stated that the housing crisis was only in the making.

Revue Française de Civilisation Britannique, XX-3 | 2015 
26 As for UKIP, it adopted an ambivalent attitude, positioning itself both against the Coalition's welfare measures (promising to scrap the bedroom tax and continue to pay Housing Benefit to young people) but also against a Mansion Tax. ${ }^{55}$ Its manifesto was not remarkable for its proposals to address the shortage (more brown field sites and fewer empty homes), as they had been mooted by other parties before or its stress on localism but for its clear link between migration and housing problems. Indeed, it committed itself to restricting access to social housing and RTB to British citizens.

In 2015, it fell to the Green Party to take up the radical and politically controversial proposals put forward by housing specialists to address the housing crisis. In its manifesto, the party denounced the current situation - without using the term 'crisis' though - and put it down to three reasons: the financialisation of housing, the end of investment in public building and uncontrolled private rented sector. ${ }^{56}$ In keeping with the proactive stance of its one and only MP regarding housing ${ }^{57}$, the party listed in three policy-packed pages a number of far more interventionist measures (giving power to the Bank of England to limit the size of mortgages, making developments more evenly distributed across the country, taking action on empty homes, ending the RTB, providing 500,000 socially rented homes etc.) Tellingly, these also encompassed the demand side of the problem (making buy-to-let less attractive, scrapping Help to Buy schemes) and the structural one (diversifying the construction industry), hence showing the influence of academic work on the party's proposals. ${ }^{58}$

\section{The electoral dimension of housing}

Having charted the rise of housing activism, its causes and the place occupied by housing in the campaign, we need to turn to the reaction of British voters. How did the electors react to the growing salience of housing in the debate prior to polling day? If statistics on voting behaviour on the basis of tenure are not available at the time of writing (September 2015), we can at least resort to pre-election polls to fathom the views of the British electorate on the housing crisis.

Housing offers an electoral paradox, if we are to go by Ipsos Mori polls: on the one hand, the salience of housing grew between 2013 and 2014, with 13\% of interviewees thinking housing was the most important issue facing Britain in the summer of 2014 (up 3\% over a year and two positions). ${ }^{59}$ Those interviewees were young (25-34), Labour voters, C2 workers, belonged to BME groups and lived in the South East. This was corroborated by another poll in January 2015, conducted on behalf of the Chartered Institute of Housing, that showed that housing was more salient in 2015 than in the two previous general elections and a very high proportion of British people considered there was housing crisis (75\%, with $44 \%$ strongly agreeing) and that parties should talk more about housing (82\%). ${ }^{60}$ In a country where Nimbyism runs deep, the proportion of people (including in small villages) in favour of more housebuilding had gone up surprisingly, as a much trumpeted government press release showed: the British Social Attitude Survey revealed that the proportion of those in favour of more housebuilding had gone from $28 \%$ to $47 \%$ between 2010 and 2013 while that of those opposed declined from $46 \%$ to $31 \% .{ }^{61}$

On the other hand, housing remained low in voters' priorities with only $5 \%$ saying it would determine their vote. ${ }^{62}$ Nationally, the issue was further down the list of concerns than the NHS, immigration, the economy and unemployment. Only in London was it 
among the three most salient issues and $28 \%$ of the residents thought it was the top issue. Furthermore, although a majority of British people were prepared to agree that there was a national housing crisis, only $37 \%$ thought the crisis was local. One explanation could be that in a society dominated by owner occupiers, the housing crisis remains above all a private and social renters' issue and one's tenure makes a fundamental difference to one's perception of the situation as well as one's home satisfaction. ${ }^{63}$ Most voters know about the crisis, fewer (fortunately) experience it first-hand.

However, the voices of private (and social) renters are not completely drowned out by those of owner-occupiers. Prior to the election, housing was expected to bear on electoral results in at least 16 of the most marginal constituencies where private or social renters represent $40 \%$ of the population as well as the four seats where they outnumber home owners. Mobilising this category was thought by some to have the potential to swing the electoral result of marginal seats. ${ }^{64}$ Furthermore, the changing British party system, combined with tenure, appeared to have the potential to hurt the two main parties. Support for UKIP was indeed up among home owners $(+11 \%)$, who traditionally are more likely to vote Conservative - except during the Blair years - as well as among social renters $(+12 \%)$ who are more likely to vote Labour. In January 2015 , on the basis of tenure, the outlook for the Conservatives was not good: their support among home owners (the section of the electorate most likely to turn out) was down $8 \%$, while support for Labour was up $5 \%$. Their respective standing was mirrored among mortgage holders $(-2 \%$ and $+4 \%$ ) and voting intentions for Labour were up among all tenured voters especially among private renters, a fast expanding category of the population. But unfortunately for Labour, they are less likely to turn out to vote. ${ }^{65}$ Finally, most voters in the capital were opposed to Conservative housing policy: polls found that $51 \%$ of London voters considered the Conservatives ' manifesto pledge to extent the right to buy to housing association tenants to be the wrong priority ( $30 \%$ a good idea) while $60 \%$ thought that Labour's proposed Mansion Tax on properties was a good thing ( $28 \%$ didn't). ${ }^{66}$ With many polls predicting another hung parliament and placing Labour and the Conservatives neck and neck, housing, in the weeks leading to the election, appeared to be well placed to make a difference to the final result. We shall have to wait for the detailed analysis of the vote to see how it played out at the local level, now that the result of the general election is known.

\section{Conclusion}

That the Conservatives managed to win the general election with a small majority is not just an indication of the success and effectiveness of negative campaigning on their part, but also of the limited impact housing has on general election results these days. Unlike in the 1950s and 1960s or even the 1980s (with the Right to Buy), housing issues are no longer able to sway voters' choices and bear on the final result. Political parties are aware of the decline of its electoral strength and, apart from the Greens, have tailored their manifesto to its waning influence.

However, the run-up to the 2015 general election held out the promise of a change as it was marked by renewed activism and the positioning of housing organisations against government policies. The debate and the mobilisation around housing policies - past and future - was given a wider echo in the press, and this echo, combined with the higher visibility of the housing movement, helped make the issue more salient than at any other 
general election since the 1980s. The higher salience, in turn, prompted political parties with the exception of the Conservatives - to include more detailed and ambitious proposals - although they fall short of what is needed - in their manifesto to tackle the housing crisis. The media coverage and the activists' tactics had convinced them of the need to broaden their housing pledges beyond home-ownership and think more radically. Nevertheless, the 2015 election demonstrated once again that housing's appeal as an electoral issue remains limited to a (growing) minority of the British population, those mostly housed in the private and rented sectors as well as homeless households: i.e. the persons least likely to turn out to vote. It has also become a local issue, with Londoners and people living in the South-East most likely to feel the pinch and be affected by the housing shortage and its consequences. In a country where home-ownership and private consumption are dominant, voting behaviour is strongly influenced by the state of the economy and the perceived economic competence attached to political parties.

The election of the Conservative party in May 2015 was soon followed by the announcement of further cuts to housing finance in the July Budget as well as other financial measures. ${ }^{67}$ These demonstrate the priority given by the Conservatives to reducing public spending on housing and confirm their determination to place the social housing sector on a self-financing and commercial basis. These measures will further reduce state intervention in the housing sector and move housing further away from the welfare state. They may bring down the cost of housing to the tax payer but whether they, along with the much criticised government's flagship Starter Home programme, ${ }^{68}$ will help to solve the housing crisis by 2020 is another matter.

\section{BIBLIOGRAPHY}

APPS, P. 'Right to Buy Extension would hit borrowing and could push landlords into insolvency", Inside Housing, 14 April 2015.

BARKER, K. Review of Housing Supply: Securing our Future Housing Needs. London, HM Treasury, 2003. BBC News, "Social Cleansing housing benefit cap row: Duncan Smith hits back", 24 April 2012.

BOOTH, R. “Homes for Britain rally puts housing firmly on housing radar", The Guardian, 17 March, 2015.

CHANDLER, D. \& DISNEY, R. Extending RTB: Risks and Uncertainties, IFS Briefing Note, BN171. London: Institute for Fiscal Studies, 2015.

COLLINSON, P. "What is the mansion tax and can the rich wriggle out of it?", The Guardian, 26 September 2014.

DEPARTMENT FOR COMMUNITIES AND LOCAL GOVERNMENT. Homes for the Future, more

Affordable, more Sustainable, Cm 7191. London: DCLG, 2007.

DEPARTMENT FOR COMMUNITIES AND LOCAL GOVERNMENT. Spending Review, Housing Settlement, Letter by Grant Shapps. 20/10/2010. 
DE CASTELLA, T. “Why can't the UK build 240,000 houses a year”, BBC News, 13 January 2015.

DOUGLAS, D. “Over 50,000 families shipped out of London Boroughs", The Independent, 29 April 2015

DOUGLAS, D. “Government considered Right to Buy as unreasonable”, Inside Housing, 20 April 2015.

DOUGLAS, D. 'Landlords threaten Legal Action over Right to Buy extension', Inside Housing, 25 March 2015.

DUXBURY, N. \& McCABE, J. “The Rise of the Housing Activist”, Inside Housing, 1 May 2015. ESPING-ANDERSEN, G. Three Worlds of Welfare Capitalism. Cambridge: Polity Press, 1990.

FEE, D. La crise du logement en Angleterre, quatre décennies de politiques de logement de la ville, 1977-2013 . Paris: Michel Houdiard, 2013.

FORREST, R. \& MURIE, A. Selling the Welfare State: the Privatization of Public Housing. London: Routledge, 1988.

HARINGEY COUNCIL \& CIH. Experiences and Effects of the Benefit Cap in Haringey. CIH, London, 2013.

KLIER, S. "Housing Policies in the General Election: what do Experts think?", The Guardian, $23 / 04 / 2015$.

LUSHER, A. « New Era Estate Victory », The Independent, 19 December /2014.

MALPASS, P. More Coherent than Sustainable :A Critique of Contemporary British Housing Policy. Unpublished, 2007.

MARSHALL, B. « The Home Front : why Housing will be a key general battleground », New Statesman, 10 February 2015.

MEMOM, A. “Red Ed's Mansion Tax Meltdown”, The Mail, 18 April 2015.

NATIONAL HOUSING FEDERATION, Response to the announcement of an extension to the RTB to housing associations, 26 May 2015, see www.housing.org.uk/media/press-releases/response-tothe-announcement-of-an-extension-to-the-RTB-to-housing-ass, accessed 25 July 2015.

SALVIRK, B. \& CREWE, I. A Decade of Dealignment. Cambridge: Cambridge UP, 1983.

SHELTER, What's wrong with the Bedroom Tax, Shelter Briefing, 2013, http:// england.shelter.org.uk/__data/assets/pdf_file/0020/650630/Bedroom_tax__Shelter_briefing_March_2013.pdf THE COALITION. Our Programme for Government. London: HM Government, 2010.

THE CONSERVATIVE PARTY. Invitation to Join the Government of Britain. London: The Conservative Party, 2010.

The CONSERVATIVE PARTY. The Conservative Party Manifesto, Strong Leadership, A Clear Economic Plan, A Brighter more Secure Future. London: The Conservative Party, 2015

THE LABOUR PARTY. Britain can get Better, The Labour party Manifesto. London: The Labour Party, 2015.

THE LIBERAL DEMOCRATS. The 2015 Manifesto: Stronger Economy, Fairer Society and Opportunity for All. London: The Liberal Democrats, 2015.

THE GREEN PARTY. For the Common Good, The Green Manifesto. London: The Green Party, 2015, p. 41. 
WELLMAN, A. "Occupy Protestors in bid to shape housing policy”, Inside Housing, 26 January 2012.

WINTOUR, P. "Mansion Tax could be very disruptive for housing market”, The Guardian, 25 September 2014.

\section{NOTES}

1. B. SALVIRK \& I. CREWE, A Decade of Dealignment, Cambridge: Cambridge UP, 1983. See also R. FORREST \& A. MURIE, Selling the Welfare State: the Privatization of Public Housing, London: Routledge, 1988.

2. P. MALPASS, More Coherent than Sustainable: a Critique of Contemporary British Housing Policy, unpublished, 2007.

3. G. ESPING-ANDERSEN, Three Worlds of Welfare Capitalism, Cambridge: Polity Press, 1990.

4. The decision to speed up the transfer of council housing under Tony Blair to the voluntary sector led to the foundation of the Defend Council Housing organisation in 2004 for instance.

5. For this first section, I shall draw on the timeline and information published in Inside Housing on 1May 2015, see Nick DUXBURY \& Jess MCCABE, "The Rise of the Housing Activist", Inside Housing, 1 May 2015.

6. DEPARTMENT FOR COMMUNITIES AND LOCAL GOVERNMENT, Spending Review, Housing Settlement, Letter by Grant Shapps, 20/10/2010.

7. DCLG, The Benefit Cap (Housing Benefit) Regulations, 2012, www.legislation.uk/uksi/2012/2994/ introduction/made, accessed 24 July 2015.

8. Alex WELLMAN, "Occupy Protestors in bid to shape housing policy", Inside Housing, 26 January 2012.

9. A. LUSHER, « New Era Estate Victory », The Independent, 19 December 2014.

10. See Grant Shapps' statement: "We must end the housing crisis in the next generation but our plan is working when you look at the facts. We are going to build a new generation of garden cities", in Robert ВООTH, "Homes for Britain rally puts housing firmly on housing radar", The Guardian, 17 March, 2015.

11. THE CONSERVATIVE PARTY, Invitation to Join the Government of Britain, London: The Conservative Party, 2010, p. 76.

12. The COALITION, Our Programme for Government, London: HM Government, 2010.

13. DCLG, Homes for the Future, more Affordable, more Sustainable, Cm 7191, London: DCLG, 2007.

14. Kate BARKER, Review of Housing Supply: Securing our Future Housing Needs, London, HM Treasury, 2003.

15. DCLG, Table 209, Permanent dwellings completed by tenure and country, hhtps:///www.gov.uk/ government/statistical-data-sets/live-tables-on-house-building, accessed 13 July 2015.

16. Tom DE CASTELLA, "Why can't the UK build 240,000 houses a year", BBC News, 13 January 2015.

17. For an overview of these problems, see David FEE, La crise du logement en Angleterre, quatre décennies de politiques de logement de la ville, 1977-2013, Paris: Michel Houdiard, 2013.

18. DCLG, Table 2009, op.cit.

19. Alan HOLMANS, New Estimates of Housing Demand and Need in England, 2011 to 2031, Tomorrow Paper Series no 16, Town and Country Planning Association, 2013 p. 5.

20. Nick DUXBURY and Jesse McCABE, op.cit.

21. DCLG, English Housing Survey, Headline Report, 2013-2014, London: DCLG, 2015, pp. 8-12.

22. Ibid., pp. 19-24.

23. Ibid., p. 32. 
24. SHELTER, http://england.shelter.org.uk/campaigns/why_we_campaign/ housing_facts_and_figures, accessed 21 July 2015.

25. DCLG, Table 600, Rents, lettings and Tenancies, number of households on local authorities' housing waiting lists, http://data.gov.uk/dataset/ households_on_local_authorities_housing_waiting_lists_excluding-households-waiting-fortransfers, accessed 21 July 2015.

26. Housing was the $11^{\text {th }}$ most often quoted topic on TV and the $12^{\text {th }}$ in newspapers from March to May, see blog.lboro.ac.uk/general-election/media-coverage-of-the-2015-campaign-report-5/

27. Haringey Council and $\mathrm{CIH}$, Experiences and Effects of the Benefit Cap in Haringey, $\mathrm{CIH}$, London, 2013, p. 6.

28. BBC News, "Social Cleansing housing benefit cap row: Duncan Smith hits back", 24 April 2012.

29. Daniel DOUGLAS, "Over 50,000 families shipped out of London Boroughs", The Independent, 29 April 2015.

30. London Assembly, Housing Committee, op. cit., p. 19.

31. DCLG, Housing Benefit Amendment Regulations, 2012, London: DCLG, www.legilsation.gov.uk/ uksi2012/3040/contents/made accessed 24 July 2015.

32. Ibid.

33. SHELTER, What's wrong with the Bedroom Tax, Shelter Briefing, 2013, http:// england.shelter.org.uk/_data/assets/pdf_file/0020/650630/Bedroom_tax_-

_Shelter_briefing_March_2013.pdf, accessed 24 July 2015.

34. Patrick COLLINSON, "What is the mansion tax and can the rich wriggle out of it?", The Guardian, 26 September 2014.

35. See this article by Steve SWINFORD, The Telegraph, 20 October 2014.

36. Adam MEMOM, “Red Ed's Mansion Tax Meltdown”, The Mail, 18 April 2015.

37. Patrick WINTOUR, "Mansion Tax could be very disruptive for housing market", The Guardian, 25 September 2014.

38. See Greg Clark's, the Communities Secretary, statement on https://www.go.uk/government/ news/over-a-million-more-people-given-the-chance-to-own-their-own-home, accessed 25 July 2015.

39. THE CONSERVATIVE PARTY, The Conservative Party Manifesto, Strong Leadership, A Clear Economic Plan, A Brighter more Secure Future, London: The Conservative Party, 2015

40. DCLG, Table 678, Social Housing Sales, Annual Sales by Scheme, 1980-81 to 2013-14, https// www.gov.uk/government/statistical-data-sets/live-tables-on-social-housing-sales, accessed 13 July 2015.

41. Daniel DOUGLAS, "Government considered Right to Buy as unreasonable", Inside Housing, 20 April 2015.

42. 800,000 housing associations tenants already enjoyed the Right to Acquire, namely those living in homes built or bought by a non-cooperative association with the help of a social housing grant after 1997, and with a tenancy going back between 2 to 5 years depending on the start of it see England.shelter.org.uk/get_advice/social_housing/ buying_your_home/right_to_acquire, accessed 25 July 2015 . Besides, only 221,000 tenants are thought to be eligible and able to afford it.

43. The Scottish government decided to end the RTB in Scotland on $1^{\text {st }}$ August 2016 and the Welsh government has decided to halve discounts as a first step towards full abolition.

44. Daniel DOUGLAS, 'Landlords threaten Legal Action over Right to Buy extension', Inside Housing , 25 March 2015.

45. $60 \%$ of the 8,000 people questioned said the policy was unfair, see Pete APPS, 'Tories Pledge to extend the Right to Buy to Housing Associations', Inside Housing, 14 April 2015. 16\% only said it was the best way of tackling the housing crisis and $27 \%$ only said it was a good use of tax payers money. 
46. NATIONAL HOUSING FEDERATION, Response to the announcement of an extension to the RTB to housing associations, 26 May 2015, see www.housing.org.uk/media/press-releases/responseto-the-announcement-of-an-extension-to-the-RTB-to-housing-ass, accessed 25 July 2015.

47. Pete APPS, 'Right to Buy Extension would hit borrowing and could push landlords into insolvency", Inside Housing, 14 April 2015.

48. Daniel CHANDLER, Richard DISNEY, Extending RTB: Risks and Uncertainties, IFS Briefing Note, BN171, London: Institute for Fiscal Studies, 2015.

49. P. MALPASS, op. cit.

50. S. KLIER, "Housing Policies in the General Election: what do Experts think?", The Guardian, $23 / 04 / 2015$.

51. D. FEE, op. cit.

52. THE CONSERVATIVE PARTY, op. cit.

53. THE LABOUR PARTY, Britain can get Better, The Labour party Manifesto, London: The Labour Party, 2015.

54. THE LIBERAL DEMOCRATS, The 2015 Manifesto: Stronger Economy, Fairer Society and Opportunity for All, London: The Liberal Democrats, 2015.

55. UKIP, Believe in Britain, UKIP Manifesto 2015, London: UKIP.

56. THE GREEN PARTY, For the Common Good, The Green Manifesto, London: The Green Party, 2015, p. 41.

57. In July 2014, Caroline Lucas introduced a Private Member's Housing Bill to address problems in the private rented sector. She also published a housing charter for Brighton.

58. See Pre-election statement by the Highbury Group on Housing Delivery, Policies on housing supply for the next Government, www.westminster.ac.uk. The author wishes to thank Duncan Bowie here for his help.

59. See 2014 Economist/Ipsos MORI Issues Index 2014 aggregate data, www.ipsos-mori.com/ researchpublications/researcharchive/3507, accessed 6 August 2015.

60. See article by Ben MARSHALL, www.ipsos-mori.com/researchpublications/ researcharchives/3519/Mps-and-public-sense-housing-crisis-but-less-so-locally.aspx, accessed 7 July 2015.

61. DCLG, Public Attitudes to New Housebuilding, see https://www.gov.uk/government/ publications/british-social-attitudes-survey-2013-attitudes-to-new-house-building

62. Ben MARSHALL, "The Home Front : why Housing will be a key general battleground", New Statesman, 10 February 2015.

63. See for clues, IPSOS MORI, www.ipsos-mori.com/researchpublications/researcharchive/3402, accessed 6 August 2015.

64. Ben MARSHALL, op. cit.

65. Ibid.

66. Dave HILL, "Most Londoners oppose RTB and back Mansion Tax-new poll", The Guardian, 16 April 2015.

67. Among these are $1 \%$ cuts to social housing rents, a lower benefit cap, abolition of Housing Benefit for the under 21s, higher rents for high-earning social tenants.

68. Shelter demonstrated that average earning families will be priced out of these homes in $58 \%$ of local authorities by 2020, see http://blog.shelter.org.uk/2015/08/non-starter-homes/, accessed 9 September 2015. 


\section{ABSTRACTS}

Unlike previous elections, the 2015 general election saw housing move to the foreground of political debate. The visibility of the issue was increased by the rise of a housing activist movement that was given extensive coverage in the media but also by the worsening housing crisis which in turn made some of the policy decisions and manifesto announcements more controversial. The article examines these issues and tries to assess whether the higher visibility of housing influenced voting intentions and the election results.

Contrairement aux élections précédentes, les élections parlementaires britanniques de 2015 ont été marquées par le retour sur le devant de la scène de la question du logement. L'essor d'un mouvement militant, relayé par une large couverture médiatique, a en effet contribué à faire du sujet un thème électoral. Son importance a été renforcée par l'aggravation de la crise du logement qui elle-même a donné aux choix politiques opérés entre 2010 et 2015 et aux engagements électoraux un caractère éminemment polémique. L'article revient donc sur ces causes et tente d'évaluer si la visibilité accrue du thème du logement a influencé les intentions de vote et les résultats électoraux.

INDEX

Mots-clés: Logement, militants, construction, statuts d'occupation, propriété.

Keywords: housing, activists, housebuilding, tenures, Right to Buy.

\section{AUTHOR}

DAVID FÉE

Université Sorbonne Nouvelle-Paris 3 